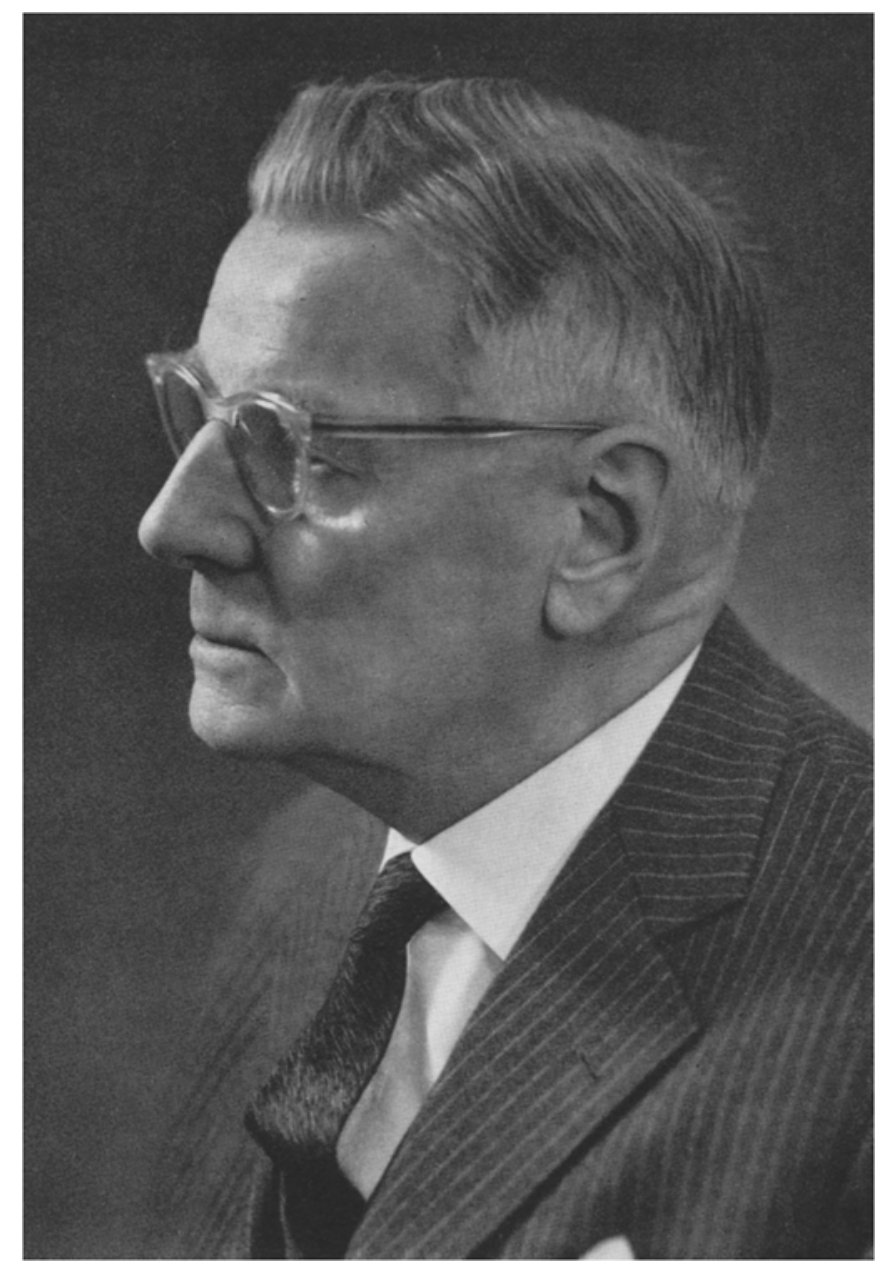

Foto Blankhorn, Göttingen

\title{
RICHARD HARDER
}

die besten Wünsche zum 80 . Geburtstag am 21. März 1968

von Redaktion und Verlag der Zeitschrift „Planta“ 